\title{
Aortic stent graft injury over active blood flow: over the fence
}

\author{
Mitsuhiko Takewa, Sei Komatsu, Satoru Takahashi, Kazuhisa Kodama
}

Cardiovascular Center, Osaka Gyoumeikan Hospital, Osaka, Japan

Correspondence to Dr Sei Komatsu, plaquemap@yahoo.co.jp

Accepted 2 March 2018

\section{DESCRIPTION}

A 72-year-old woman was admitted to our hospital complaining of chest pain at rest. She underwent thoracic endovascular repair (TER) using three stent grafts $($ GORE TAG $34 \times 150,34 \times 200$ and $26 \times 200 \mathrm{~mm}$; W. L. Gore $\&$ Associates, Flagstaff, Arizona, USA) with type B aortic dissection 5 years earlier (figure 1A). Coronary CT angiography (CTA) findings were inconclusive because of remarkable massive calcification in all coronary arteries. As a low-density area suspected of mural thrombus inside the second stent graft was detected (figure 1B), non-obstructive angioscopy was performed to evaluate graft failure besides invasive coronary angiography. ${ }^{1}$ No significant stenosis was found using invasive coronary angiography; however, suspicious blood flow through the graft was observed at the aneurysmal descending aorta in the middle of the second graft (figure 2 and video 1). Being uninfluenced by aortic blood flow, it was thought to exist over the graft. At the site, neither the first nor the third grafts overlapped. The graft might have separated from the stent or leaked blood might have invaded the graft because the flow spread to the graft's posterior side. No mural thrombi or massive plaques were detected.

A
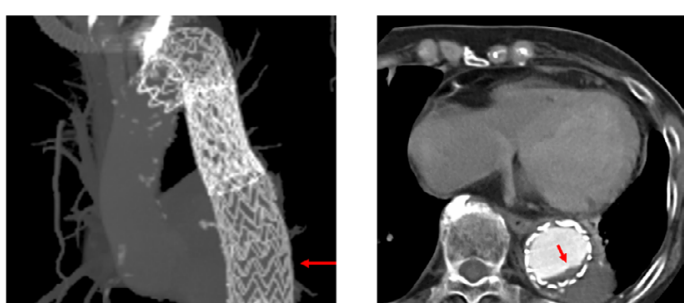

Figure $1 \mathrm{CT}$ angiography images at the site of suspicious blood flow through the graft detected using non-obstructive angioscopy. (A) A minimal intensity projection image of the thoracic aorta. Two stent grafts $(34 \times 150 \mathrm{~mm}$ and $34 \times 200 \mathrm{~mm})$ were shown. The site of suspicious blood flow was at the level shown with a red arrow. (B) An axial image. Suspicious blood flow was detected through the graft using non-obstructive angioscopy (a red arrow).

Check for updates

To cite: Takewa M, Komatsu S, Takahashi S, et al. BMJ Case Rep Published Online First: [please include Day Month Year]. doi:10.1136/bcr-2018224812

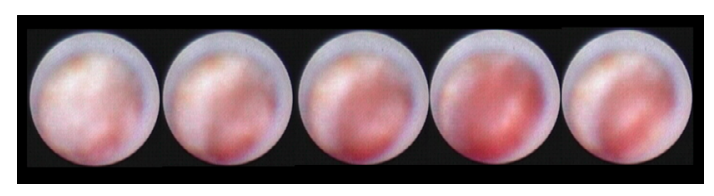

Figure 2 Continuous angioscopic images showing active blood flow through the graft.

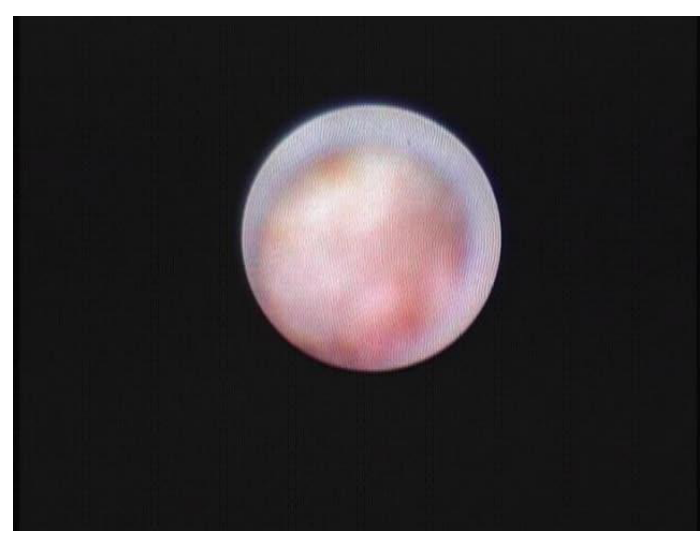

Video 1 Angioscopic movie showing suspicious blood flow over the graft.

CTA at the $10 \%$ R-R interval of ECG gating showed a low-density area inside the stent graft. Its border moved with the cardiac cycle; however, the stent shape remained unchanged (video 2). An endoleak may have been detected using angioscopy. Angioscopy may help stratify risks of aortic TER-related complications. ${ }^{2}$ Non-obstructive angioscopy successfully showed blood flow over the graft, potentially from an endoleak, which might be related to a partial stent graft injury. In this case, non-obstructive angioscopy was performed safely during the catheter procedure and the patient remained free from embolic complications within 30 days. Long-term follow-up and more evidence

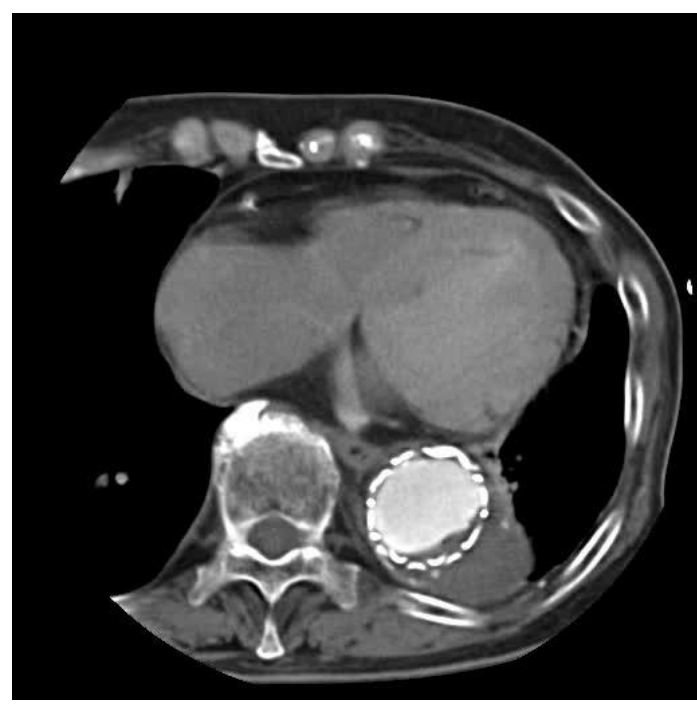

Video 2 CT angiography at the 10\% R-R interval of the ECG gating from $0 \%$ to $100 \%$. 
are needed to assess the significance of active blood flow over the graft detected using angioscopy.

Contributors MT wrote the first version of the manuscript. SK and ST performed the supervision of the manuscript and gave expert opinion. KK supervised all the processes and gave final approval for the version of the manuscript.

Funding The authors have not declared a specific grant for this research from any funding agency in the public, commercial or not-for-profit sectors.

Competing interests KK, who is the president of Inter-tec Medicals developed non-obstructive angioscopy. SK is a technical consultant for Nemoto Kyorin-do and other authors have no conflict of interest.

Patient consent Obtained.
Provenance and peer review Not commissioned; externally peer reviewed.

(c) BMJ Publishing Group Ltd (unless otherwise stated in the text of the article) 2018. All rights reserved. No commercial use is permitted unless otherwise expressly granted.

\section{REFERENCES}

1 Komatsu S, Ohara T, Takahashi S, et al. Early detection of vulnerable atherosclerotic plaque for risk reduction of acute aortic rupture and thromboemboli and atheroemboli using non-obstructive angioscopy. Circ J 2015;79:742-50.

2 Murakami T, Komatsu S, Kodama K, et al. Detection of vulnerable atherosclerotic plaque during thoracic endovascular aortic repair using nonobstructive angioscopy. $J$ Int Med Res 2017. doi: 10.1177/0300060517731681. [Epub ahead of print 1 Jan 2017].

Copyright 2018 BMJ Publishing Group. All rights reserved. For permission to reuse any of this content visit http://group.bmj.com/group/rights-licensing/permissions.

BMJ Case Report Fellows may re-use this article for personal use and teaching without any further permission.

Become a Fellow of BMJ Case Reports today and you can:

- Submit as many cases as you like

- Enjoy fast sympathetic peer review and rapid publication of accepted articles

- Access all the published articles

Re-use any of the published material for personal use and teaching without further permission

For information on Institutional Fellowships contact consortiasales@bmjgroup.com

Visit casereports.bmj.com for more articles like this and to become a Fellow 